\title{
Rates of bacterial co-infections and antimicrobial use in COVID-19 patients: a retrospective cohort study in light of antibiotic stewardship
}

\author{
Kathrin Rothe ${ }^{1}$ (D) S Susanne Feihl ${ }^{1} \cdot$ Jochen Schneider $^{2} \cdot$ Fabian Wallnöfer $^{2} \cdot$ Milena Wurst $^{2} \cdot$ Marina Lukas $^{2}$. \\ Matthias Treiber ${ }^{2} \cdot$ Tobias Lahmer $^{2}$ - Markus Heim ${ }^{3} \cdot$ Michael Dommasch $^{4} \cdot$ Birgit Waschulzik $^{5}$ - Alexander Zink ${ }^{6}$. \\ Christiane Querbach $^{7}$ • Dirk H. Busch ${ }^{1,8} \cdot$ Roland M. Schmid $^{2} \cdot$ Gerhard Schneider $^{3}$ - Christoph D. Spinner ${ }^{2,8}$
}

Received: 2 July 2020 / Accepted: 1 October 2020/Published online: 2 November 2020

(C) The Author(s) 2020

\begin{abstract}
The coronavirus disease 2019 (COVID-19) caused by the severe acute respiratory syndrome coronavirus 2 (SARS-CoV-2) has spread worldwide. Bacterial co-infections are associated with unfavourable outcomes in respiratory viral infections; however, microbiological and antibiotic data related to COVID-19 are sparse. Adequate use of antibiotics in line with antibiotic stewardship (ABS) principles is warranted during the pandemic. We performed a retrospective study of clinical and microbiological characteristics of 140 COVID-19 patients admitted between February and April 2020 to a German University hospital, with a focus on bacterial co-infections and antimicrobial therapy. The final date of follow-up was 6 May 2020. Clinical data of 140 COVID-19 patients were recorded: The median age was 63.5 (range 17-99) years; 64\% were males. According to the implemented local ABS guidelines, the most commonly used antibiotic regimen was ampicillin/sulbactam (41.5\%) with a median duration of 6 (range 1-13) days. Urinary antigen tests for Legionella pneumophila and Streptococcus peumoniae were negative in all cases. In critically ill patients admitted to intensive care units $(n=50)$, co-infections with Enterobacterales $(34.0 \%)$ and Aspergillus fumigatus (18.0\%) were detected. Blood cultures collected at admission showed a diagnostic yield of $4.2 \%$. Bacterial and fungal co-infections are rare in COVID-19 patients and are mainly prevalent in critically ill patients. Further studies are needed to assess the impact of antimicrobial therapy on therapeutic outcome in COVID-19 patients to prevent antimicrobial overuse. ABS guidelines could help in optimising the management of COVID-19. Investigation of microbial patterns of infectious complications in critically ill COVID-19 patients is also required.
\end{abstract}

Keywords COVID-19 · Antibiotic stewardship $\cdot$ Bacterial co-infections $\cdot$ Diagnostic stewardship

Supplementary Information The online version of this article (https:// doi.org/10.1007/s10096-020-04063-8) contains supplementary material, which is available to authorized users.

Kathrin Rothe

kathrin.rothe@tum.de

1 Institute for Medical Microbiology, Immunology and Hygiene,

Technical University of Munich, School of Medicine, Trogerstr. 30, 81675 Munich, Germany

2 Department of Internal Medicine II, Technical University of Munich, School of Medicine, Munich, Germany

3 Department of Anaesthesiology and Intensive Care Medicine, Technical University of Munich, School of Medicine, Munich, Germany
4 Department of Internal Medicine I, Technical University of Munich, School of Medicine, Munich, Germany

5 Institute of Medical Informatics, Statistics and Epidemiology, Technical University of Munich, School of Medicine, Munich, Germany

6 Department of Dermatology and Allergology, Technical University of Munich, School of Medicine, Munich, Germany

7 Hospital Pharmacy, Technical University of Munich, School of Medicine, Munich, Germany

8 German Center for Infection Research (DZIF), Partner Site Munich, Munich, Germany 


\section{Introduction}

In December 2019, patients presenting with respiratory tract infections due to a formerly unidentified microbial agent were reported in Wuhan, China. A novel beta-coronavirus, severe acute respiratory syndrome coronavirus 2 (SARS-CoV-2), was subsequently identified as the causative pathogen. The corresponding disease was then named coronavirus disease 2019 (COVID-19) by the World Health Organization (WHO) $[1,2]$. SARS-CoV-2 is reported to be more infectious than SARS-CoV, and the outbreak led to a pandemic. As of 5 May 2020, more than 3 million cases and over 200,000 deaths due to COVID-19 have been confirmed worldwide. Although most people develop mild or uncomplicated illness, severe disease requiring hospitalisation is also observed in a subset of patients [3]. In severe cases, oxygen support and intensive care unit (ICU) admission are required, and complications such as acute respiratory distress syndrome (ARDS), sepsis, and multi-organ failure are observed $[4,5]$. The WHO guidelines for the clinical management of COVID-19 advise clinicians to collect blood cultures (BCs) as well as respiratory samples from the upper respiratory tract for bacterial cultures, and to start empirical antimicrobial treatment only in severe cases [4].

Although the symptoms, clinical course, and risk factors for disease severity associated with COVID-19 have been analysed [6], data on bacterial or fungal co-infections in COVID-19 are sparse. Generally, respiratory viral infections are a risk factor for bacterial co-infections, which then increase disease severity and mortality. It has been shown that sepsis and ventilator-associated pneumonia are a frequently observed complication in COVID-19 patients [7].

In COVID-19 patients, bacterial and fungal co-infection rates are generally low, with higher rates in critically ill ICU-patients, but antimicrobial coverage was noted in the majority of patients [8-10]. Microbiological diagnosis of coinfection is complex and data on pathogens causing such infections in COVID-19 patients are limited, as most studies do not report or identify co-infections in COVID-19 cases [7, 9, $11,12]$. In published case series, bacterial and fungal coinfections in COVID-19 patients due to gram-negative pathogens and Aspergillus spp. were described [12-14]. Lack of data on bacterial and fungal cultures may be due to the absence of routine microbiological workup, as health care workers collecting respiratory samples and laboratory technicians processing these samples are at risk of exposure [15]. Notably, the rate of antibiotic use was considerably higher than the incidence of confirmed secondary infections in COVID-19 patients [16]. Based on only a few studies without defined information on sampling strategies, a bacterial or fungal co-infection rate of $8 \%$ in COVID-19 patients was estimated, but $72 \%$ of all these reported COVID-19 patients received (empiric broad-spectrum) antibiotic therapy [9].
Overuse of antimicrobials increases the risk for multiresistant nosocomial secondary infections, which are associated with unfavourable clinical outcomes [17]. Therefore, practice of empirical antibiotic coverage in COVID-19 patients must be carefully evaluated.

The goal of antibiotic stewardship (ABS) programmes is to optimise the use of antimicrobial agents while reducing the risks of the emergence of antimicrobial resistance, side effects, and pharmaceutical costs. ABS strategies decrease antimicrobial use; thus, national and international guidelines encourage hospitals to implement local ABS guidelines to optimise treatment and de-escalation strategies [18, 19]. So far, COVID-19specific ABS interventions are sparse while they have huge beneficial potential in the management of the pandemic by optimising treatment strategies, antibiotic use, and diagnostic stewardship [20-22] . Our institution implemented a local ABS standard operation procedure (SOP) based on Zhang and colleagues [23] on 18 March 2020, for diagnostic measures and empirical antimicrobial coverage with a narrowspectrum aminopenicillin/beta-lactamase inhibitor combination. Physicians were instructed to collect two sets of BCs and perform a urinary antigen test for Legionella pneumophila and Streptococcus pneumoniae in each patient with suspected or confirmed COVID-19 upon hospital admission. During hospitalisation, respiratory samples were routinely collected only from critically ill patients.

The present study aimed to analyse the microbiological findings and antibiotic therapies applied in our cohort to widen existing knowledge on bacterial co-infections as well as on antibiotic regimens for COVID-19.

\section{Materials and methods}

We performed a retrospective single-centre cohort study of 140 hospitalised adult patients (age 17-99 years) with confirmed COVID-19, admitted between February 16, 2020, and April 22, 2020, to a large university hospital with approximately 1200 beds, located in the centre of Munich, Germany. Patients were followed up until the 6 May 2020. Medical records including clinical charts and nursing records were reviewed; only the in-hospital patient course was analysed; no further outcome data are available. Initial emergency department (ED) care in patients to be hospitalised was also considered in-hospital patient course. Data collection included patient demographics, comorbidities, clinical parameters, laboratory findings, microbiological analysis information on inpatient management, hospital stay, and outcome as well as antibiotic regimen. Data extraction for laboratoryconfirmed COVID-19 patients was performed according to published methods [24, 25]: Relevant variables were defined, documented in an abstraction form, and extracted by two medical students from electronical patient files after abstractor 
training by an infectious diseases specialist and a clinical microbiologist who also monitored performance of data extraction and were available for inquires. Chart reviewers were not blinded and inter-rater agreement was not tested. Missing patient data was accepted for laboratory parameters and antibiotic therapies due to the retrospective nature of the study. The Ethics Committee of the Technical University of Munich approved the protocol of this retrospective study and waived the need to obtain consent for the collection, analysis, and publication of the data (approval no. 260/20S). Laboratory confirmation of SARS-CoV-2 was achieved by RT-PCR or serological testing. RNA was extracted from swabs using the MagNA Pure 96 system (Roche, Penzberg, Germany). A 2step in-house RT-PCR protocol as described by Corman et al. [26] was used, including the E gene assay as a screening test, followed by the Rd. gene assay test for confirmation. Serum IgM and IgG antibodies against SARS-CoV-2 were tested using a paramagnetic particle chemiluminescent immunoassay (CLIA) on iFlash immunoassay analyser (Shenzhen Yhlo Biotech Co., Shenzhen, China). Additionally, a chest computed tomography (CT) scan was performed in all patients and evaluated to identify typical CT findings for COVID-19 [27]. Patients with positive PCR or positive IgM/IgG-serology results and symptoms with or without specific COVID-19 CT features were defined as confirmed COVID-19 cases. Suspected but undiagnosed patients were excluded from the analysis.Patients were treated at the ED of our institution according to a local ABS SOP (Supplementary Fig. 1) started on March 18, 2020, and based on Zhang and colleagues [23]. This ABS guideline includes a diagnostic algorithm based on clinical, laboratory, and chest CT findings and advises on the use of microbiological and virological diagnostics as well as empirical antibiotic therapy. The SOP advised on initiation of antibiotic therapy only in cases of clinically suspected infection and elevated inflammatory parameters. The decision to start or change antimicrobial therapy was at the discretion of the physicians. Laboratory COVID-19 test results were only available with delay; therefore, initial diagnosis in the emergency setting was based on clinical condition and chest CT scans which were available and transmitted immediately. Biomarkers were available timely in the ED-setting enabling physicians to base antibiotic therapy on laboratory results. In the standard ED-workflow, laboratory test results are available prior to initiation of antibiotic therapy. However, in our retrospective study setting, we cannot control if laboratory parameters were actually noticed prior to the antibiotic prescription in every case.Urine samples were used for lateral flow antigen test detection of Legionella pneumophila serogroup 1 and Streptococcus pneumoniae (BinaxNOW®, Abott, Chicago, USA).For microbiological workup, blood was inoculated into aerobic and anaerobic BC media (BACTEC ${ }^{\text {TM }}$ Plus, Becton Dickinson, Sparks, MD, USA) via an automated BC system (BACTEC'тм Fluorescent Series, Becton Dickinson). Culture bottles were incubated for 5-7 days according to the manufacturer's recommendations. Considering the difficulty in determining the clinical significance of coagulase-negative staphylococci (CoNS) in BC, these isolates were reviewed separately based on the number of positive culture sets, the presence of intravascular devices, and patient's characteristics. Isolates were considered clinically significant (true bacteraemia) if two or more bottles yielded the same CoNS.

Primary microbiological cultures of respiratory samples were performed on Columbia agar, Schaedler agar, and Chocolate agar (prepared culture media, Becton Dickinson, Sparks, MD, USA). Gram stain identification, species identification (Matrix Assisted Laser Desorption Ionisation-Time of Flight Mass Spectrometry, Bruker Daltronics, Leipzig, Germany), and automated antimicrobial susceptibility testing (VITEK®, bioMerieux, Marcy l'Etoile, France) were performed for all relevant pathogens. Anaerobic strains were tested using minimal inhibitory concentration (MIC) test strips (Liofilchem Inc., Waltham, MA, USA).

German national standards were used to define multidrugresistant gram-negative bacteria [28]. This national classification defines four antibiotic classes with clinical relevance for treatment of gram-negative infections: carbapenems, quinolones, third-and-fourth-generation cephalosporins and ureidopenicillins. Multi-resistance of gram-negative pathogens is classified as resistance to three of these classes (3MRGN); extensive resistance is defined as resistance to all of these classes or detection of carbapenemase (4MRGN) (Supplementary Table 1).

\section{Statistics}

Continuous data is described by median (range) and categorical data by absolute and relative frequencies. Statistical significance of the association between carbapenem therapy and detection of superinfection was determined with a two-tailed Fisher's exact test using $P<0.05$ as the level of significance. Statistical analyses were performed using Microsoft Excel 2013 and IBM SPSS Statistics Version 25.0 (IBM Corp, Armonk, NY).

\section{Results}

During the study period, 140 confirmed COVID-19 patients were evaluated. On the final day of follow-up, 27 patients $(19 \%)$ were still in inpatient care (13 in general wards and 14 in ICU), 18 patients (13\%) died (6 died in general wards, and 12 died in ICU), and 95 patients $(68 \%)$ were discharged (21 with previous ICU stay and 74 with hospital stay in general wards only).

COVID-19 was diagnosed by PCR in 126 patients (90.0\%) and based on serological tests in 14 cases $(10.0 \%)$. Chest CT- 
scan findings consistent with COVID-19 symptoms were observed in 114 patients $(81.4 \%$ ) in our cohort. CT findings were unspecific in 6 cases, and a chest CT-scan was not performed in another 6 cases.

Patient characteristics, laboratory findings, microbiological workup, and antibiotic use were analysed for the entire cohort. Moreover, the cohort was divided into two subgroups based on clinical outcome: Subgroup one included patients admitted to the general ward only ( $n=84$ : moderate cases). The second subgroup included patients admitted to the ICU and all patients who died during hospital stay, regardless if death occurred on ICU or general ward ( $n=56$ : severe cases).

The median age of the cohort was 63.5 (17-99) years, and 90 (64.3\%) patients were males. In severe cases, the median age and the number of males were higher. At least one underlying comorbidity was present in $75.7 \%$, with arterial hypertension being the most frequent comorbidity; a higher frequency was observed in more severe cases. The median length of hospital stay was associated with severity of disease. The median duration of ICU stay was 11 days. Twenty-two patients (15.7\%) were admitted directly to the ICU and 41 patients (73.2\% of all ICU patients) required invasive mechanical ventilation.

The mean C-reactive protein (CRP) level, leukocyte count, and procalcitonin (PCT) level on admission were higher in severe COVID-19 patients than in moderate cases. Detailed demographic and laboratory findings are shown in Table 1.

During hospitalisation, all patients were treated in adequate isolation units to prevent the spread of the disease. Information on antibiotic therapy was not available for five patients which were all treated on general wards only. Of the remaining 135 analysed cases, most patients received antimicrobial therapy within $24 \mathrm{~h}$ of admission $(n=109,80.7 \%)$ : in 113 patients antimicrobial therapy was initiated in the ED, and in 22 patients therapy was initiated on ICU (in cases of direct admittance to ICU). Only 19 patients (14.1\%) were not administered any antimicrobial therapy during hospitalisation. The antibiotic regimen most commonly used was ampicillin/ sulbactam with or without azithromycin $(41.5 \%)$ with a median duration of 6 (1-13) days, followed by piperacillin/ tazobactam with or without azithromycin $(19.3 \%)$ with a median duration of 10 (3-26) days. Empirical use of ampicillin/ sulbactam is in line with local ABS guidelines. However, the SOP did not advise on the use of azithromycin in combination with beta-lactam antibiotics; nevertheless, it was administered in combination to 43 patients (31.9\%).

Interestingly, laboratory findings on admission appear to be different between antibiotic regimens, suggesting that high inflammatory markers influenced the physician's decision on what antimicrobial to start. Detailed information of initial empirical antibiotic therapy including duration of therapy is presented in Table 2. Administration of (broad-spectrum) antibiotic was observed more frequently in patients with high CRP or PCT values: CRP on admission was higher in patients receiving ampicillin/sulbactam than in patients receiving no antimicrobial therapy. In cases of administration of piperacillin/tazobactam, initial laboratory findings for CRP and PCT were increased. Notably, increased PCT on admission seems to be associated with adverse outcome (i.e. death), as in patients with initial median PCT of $0.1 \mathrm{ng} / \mathrm{dL}$, only $5.4 \%(3 / 56)$ died while the percentage increased to $19.2 \%(5 / 26)$ in patients with initial median PCT of $0.25 \mathrm{ng} / \mathrm{dL}$.

Changes in antibiotic therapy during hospitalisation occurred in 57 COVID-19 patients; of those, 14 patients were moderate cases and 43 patients were severe cases. Supplementary Table 2 displays changes in antibiotic therapy. Details on antimicrobial changes are calculated in reference to these 57 patients. Antibiotic de-escalation in line with ABS principles was not documented in our cohort, but in $11 \mathrm{pa}-$ tients, therapy was discontinued within 3 days of hospital admission as a result of critical revaluation. Escalation was defined as change to broad-spectrum ureidopenicillins and carbapenems with or without glycopeptides/oxazolidinones. Moreover, addition of antifungal therapy was analysed. In a few cases, changes consisted of addition of other antimicrobials such as azithromycin, ceftazidime, ceftriaxone, cefepime, tobramycin, or tigecycline. In 17 patients (29.8\%) escalation consisted of piperacillin/tazobactam therapy and theses cases were more frequent among moderate cases $(n=9$, $64.3 \%)$ than in severe cases $(n=8,18.6 \%)$. Escalation to meropenem was documented in 9 (15.8\%) COVID-19 patients in our cohort with almost equal numbers of more severe cases and moderate cases. Interestingly, escalation to piperacillin/tazobactam plus vancomycin or linezolid was rarely seen $(n=1,1.8 \%)$ while the majority of escalations to combination-regimens consisted of meropenem + vancomycin or linezolid $(n=20,35.1 \%)$ affecting especially more severe cases $(n=19,44.2 \%)$.

Intensification with antimycotic therapy was only observed in more severe cases, echinocandins were added in 5 cases $(8.8 \%)$, voriconazole in 4 cases $(7.0 \%)$, fluconazole in 6 cases $(10.5 \%)$, and addition of liposomal amphotericin-B was documented in $8(14.0 \%)$ COVID-19 patients.

Most patients received microbiological workup upon hospital admission according to the local SOP. In total, BCs were collected from 118 patients (84.3\%) and BCs were positive in 10 cases $(7.1 \%)$. True bacteraemia with confirmed bloodstream infection was detected in only 5 cases, resulting in a BC diagnostic yield of $4.2 \%$. Pathogens considered contaminants were the only cause of bacteraemia in $50 \%$ of all positive BCs. Notably, PCT on admission in cases of true bacteraemia was higher than in sterile BCs or contamination only highlighting the diagnostic value of PCT in diagnosing bloodstream infections.

For 57 COVID-19 patients (40.7\%), especially in more severe cases, follow-up BCs were collected and relevant pathogens were detected in 11 cases (7.9\%). 
Table 1 Demographic characteristics and laboratory findings

\begin{tabular}{|c|c|c|c|}
\hline & $\begin{array}{l}\text { Entire cohort } \\
(n=140)\end{array}$ & $\begin{array}{l}\text { Severe COVID-19 } \\
\text { patients }(n=56)\end{array}$ & $\begin{array}{l}\text { Moderate COVID-19 } \\
\text { patients }(n=84)\end{array}$ \\
\hline Mean age & $63.5(17-99)$ & $68.5(26-99)$ & $63(17-95)$ \\
\hline Male sex & $90(64.3 \%)$ & $40(71.4 \%)$ & $50(59.5 \%)$ \\
\hline \multicolumn{4}{|l|}{ Comorbidities } \\
\hline $\begin{array}{l}\text { Presence of any comorbidity as } \\
\text { listed below* }\end{array}$ & $106(75.7 \%)$ & $43(76.8 \%)$ & $63(75.0 \%)$ \\
\hline - Obesity & $23(16.4 \%)$ & $12(21.4 \%)$ & $11(13.1 \%)$ \\
\hline - Arterial hypertension & $68(48.6 \%)$ & $30(53.6 \%)$ & $38(45.2 \%)$ \\
\hline - Diabetes & $30(21.4 \%)$ & $16(28.6 \%)$ & $14(16.7 \%)$ \\
\hline - Coronary heart disease & $26(18.6 \%)$ & $12(21.4 \%)$ & $14(16.7 \%)$ \\
\hline - Congestive heart failure & $12(8.6 \%)$ & $5(8.9 \%)$ & $7(8.3 \%)$ \\
\hline - COPD & $7(5.0 \%)$ & $6(10.7 \%)$ & $1(1.2 \%)$ \\
\hline - Bronchial asthma & $15(10.7 \%)$ & $2(3.6 \%)$ & $13(15.5 \%)$ \\
\hline - Chronic kidney disease & $16(11.4 \%)$ & $10(17.9 \%)$ & $6(7.1 \%)$ \\
\hline - Cancer & $29(20.7 \%)$ & $15(26.8 \%)$ & $14(16.7 \%)$ \\
\hline - HIV & $5(3.6 \%)$ & $1(1.8 \%)$ & $4(4.8 \%)$ \\
\hline $\begin{array}{l}\text { - Any medical } \\
\text { immunosuppression }\end{array}$ & $15(10.7 \%)$ & $7(12.5 \%)$ & $8(9.5 \%)$ \\
\hline - Chronic liver disease & $7(5.0 \%)$ & $4(7.1 \%)$ & $3(3.6 \%)$ \\
\hline Duration of hospital stay (days) & $12(1-47)$ & $19(1-47)$ & $10(1-46)$ \\
\hline Duration of ICU stay (days) & & $11(1-38)$ & \\
\hline $\begin{array}{l}\text { Interval from hospital admission to } \\
\text { ICU admission (days) }\end{array}$ & & $1.0(0-23)$ & \\
\hline \multicolumn{4}{|l|}{ Laboratory findings on admission } \\
\hline - CRP (mg/dL) & $6.1(0.1-35)$ & $9.9(0.3-35.0)$ & $4.7(0.1-26.6)$ \\
\hline - Leukocyte (G/L) & $6.4(1.4-26.3)$ & $7.2(1.6-22.4)$ & $6.1(1.4-26.3)$ \\
\hline - PCT (ng/mL) & $0.1(0.1-18.7)$ & $0.3(0.1-18.7)$ & $0.1(0.1-5.9)$ \\
\hline \multicolumn{4}{|c|}{ Laboratory findings on day of highest CRP value } \\
\hline - CRP (mg/dL) & $14.8(0.1-50.6)$ & $27.6(1.5-50.6)$ & $8.8(0.1-33.5)$ \\
\hline - Leukocyte (G/L) & $10.2(1.8-56.6)$ & $16.1(5.9-56.6)$ & $7.8(1.8-37.4)$ \\
\hline - PCT (ng/mL) & $0.2(0.1-175.5)$ & $1.8(0.1-175.5)$ & $0.1(0.1-138.4)$ \\
\hline
\end{tabular}

Data is presented as absolute numbers and relative frequencies $(n(\%))$ or as median (range). COVID-19, coronavirus disease-2019; $I C U$, intensive care unit; $C O P D$, chronic obstructive pulmonary disease; $H I V$, human immunodeficiency virus; $C R P$, C-reactive protein; $P C T$, procalcitonin

*As defined by clinicians in admission records
Urinary antigen tests for Legionella pneumophila and Streptococcus pneumoniae were performed for 111 (79.3\%) and $107(76.4 \%)$ patients, and the results were negative in all cases.

Respiratory samples for microbiological tests were obtained only from a subset of patients on admission (17.9\%), all of whom had severe COVID-19 illness. However, the majority of cultures remained sterile or showed the presence of normal oral flora. Relevant pathogens were detected only in 3 cases, where growth of Escherichia coli $(n=1)$, Staphylococcus aureus $(n=1)$, and Klebsiella oxytoca $(n=1)$ was observed.

Most respiratory samples for follow-up microbiological tests were collected from patients admitted to the ICU $(n=$ 50). Only one respiratory sample was collected from a patient not admitted to the ICU, and it showed the presence of Klebsiella aerogenes. For ICU patients, respiratory samples were collected from 38 (76.0\%) patients for follow-up microbiological tests, and relevant pathogens were detected in 23 cases $(46.0 \%)$, showing a predominance of Enterobacterales and Aspergillus fumigatus. The pathogens detected in the samples were Enterobacter cloacae $(n=1)$, Serratia marcescens $(n=4)$, Proteus spp. $(n=3)$, E. coli $(n=6)$, Morganella morganii $(n=1)$, Citrobacter spp. $(n=3)$, Klebsiella spp. $(n=11)$, A. fumigatus $(n=9), S$. aureus $(n=$ $3)$, and $P$. aeruginosa $(n=2)$.

Neither multidrug-resistant gram-negative pathogen according to the German national classification nor a methicillin-resistant Staphylococcus aureus (MRSA) was 
Table 2 Most commonly used initial empirical antibiotic therapy

\begin{tabular}{|c|c|c|c|c|}
\hline & $\begin{array}{l}\text { COVID-19 } \\
\text { patients } \\
\text { with available } \\
\text { information on } \\
\text { empiric antibiotic } \\
\text { therapy }(n=135)\end{array}$ & $\begin{array}{l}\text { Severe COVID-19 } \\
\text { patients with available } \\
\text { information on empiric } \\
\text { antibiotic therapy } \\
(n=56)\end{array}$ & $\begin{array}{l}\text { Moderate COVID-19 } \\
\text { patients with available } \\
\text { information on empiric } \\
\text { antibiotic therapy } \\
(n=79)\end{array}$ & $\begin{array}{l}\text { Laboratory findings } \\
\text { on admission in } \\
\text { selected patients }\end{array}$ \\
\hline $\begin{array}{l}\text { No antibiotic therapy during } \\
\text { hospital stay at all }\end{array}$ & $19(14.1 \%)$ & $3(5.4 \%)$ & $16(20.3 \%)$ & \\
\hline No initial antibiotic therapy & $26(19.3 \%)$ & $8(14.3 \%)$ & $18(22.8 \%)$ & $\begin{array}{l}\text { Leukocyte count } 5.7(3.4-12.5) \mathrm{G} / \mathrm{L} \\
\text { CRP } 3.6(0.1-21.4) \mathrm{mg} / \mathrm{dL} \\
\text { PCT } 0.1(0.1-2.1) \mathrm{ng} / \mathrm{mL}\end{array}$ \\
\hline $\begin{array}{l}\text { Ampicillin/sulbactam } \\
\text { Duration of therapy (days) }\end{array}$ & $\begin{array}{l}41(30.4 \%) \\
7(1-13)\end{array}$ & $\begin{array}{l}8(14.3 \%) \\
6(3-9)\end{array}$ & $\begin{array}{l}33(41.8 \%) \\
7(1-13)\end{array}$ & \multirow{3}{*}{$\begin{array}{l}\text { Leukocyte count } 5.6(1.6-23.1) \mathrm{G} / \mathrm{L} \\
C R P 4.8(0.1-26.6) \mathrm{mg} / \mathrm{dL} \\
\text { PCT } 0.1(0.1-15.1) \mathrm{ng} / \mathrm{dL}\end{array}$} \\
\hline Ampicillin/sulbactam + azithromycin* & $15(11.1 \%)$ & $9(16.1 \%)$ & $6(7.6 \%)$ & \\
\hline Duration of therapy & $4(1-10)$ & $6(4-10)$ & $4(1-7)$ & \\
\hline $\begin{array}{l}\text { Piperacillin/tazobactam } \\
\text { Duration of therapy (days) }\end{array}$ & $\begin{array}{l}10(7.4 \%) \\
9(5-20)\end{array}$ & $\begin{array}{l}5(8.9 \%) \\
9(6-20)\end{array}$ & $\begin{array}{l}5(6.3 \%) \\
8(5-15)\end{array}$ & \multirow{3}{*}{$\begin{array}{l}\text { Leukocyte count } 6.8(2.8-22.6) \mathrm{G} / \mathrm{L} \\
\text { CRP } 9.3(0.2-26) \mathrm{mg} / \mathrm{dL} \\
\text { PCT } 0.3(0.1-18.7) \mathrm{ng} / \mathrm{mL}\end{array}$} \\
\hline $\begin{array}{l}\text { Piperacillin/tazobactam + } \\
\text { azithromycin* }\end{array}$ & $16(11.9 \%)$ & $10(17.9 \%)$ & $6(7.6 \%)$ & \\
\hline Duration of therapy (days) & $10(3-26)$ & $11.5(3-26)$ & $10(7-17)$ & \\
\hline $\begin{array}{l}\text { Meropenem } \\
\text { Duration of therapy (days) }\end{array}$ & $\begin{array}{l}1(0.7 \%) \\
10\end{array}$ & $\begin{array}{l}1(1.8 \%) \\
10\end{array}$ & 0 & \multirow{2}{*}{$\begin{array}{l}\text { Leukocyte count } 10.3(4.7-14.5) \\
\text { G/L } \\
\text { CRP } 9.6(5.7-17.8) \mathrm{mg} / \mathrm{dL} \\
\text { PCT } 0.1(0.1-0.8) \mathrm{ng} / \mathrm{mL}\end{array}$} \\
\hline $\begin{array}{c}\text { Meropenem + azithromycin* } \\
\text { Duration of therapy (days) }\end{array}$ & $\begin{array}{l}5(3.7 \%) \\
10(5-25)\end{array}$ & $\begin{array}{l}2(3.6 \%) \\
18.5(12-25)\end{array}$ & $\begin{array}{l}3(3.8 \%) \\
7.5(5-10)\end{array}$ & \\
\hline $\begin{array}{l}\text { Moxifloxacin } \\
\text { Duration of therapy (days) }\end{array}$ & $\begin{array}{l}4(3.0 \%) \\
4(2-8)\end{array}$ & $\begin{array}{l}2(3.6 \%) \\
5(2-8)\end{array}$ & $\begin{array}{l}2(2.5 \%) \\
4(3-5)\end{array}$ & $\begin{array}{l}\text { Leukocyte count } 8.2(6.3-11.1) \mathrm{G} / \mathrm{L} \\
\text { CRP } 9.0(6.1-18.1) \mathrm{mg} / \mathrm{dL} \\
\text { PCT } 0.1(0.1-0.2) \mathrm{ng} / \mathrm{mL}\end{array}$ \\
\hline $\begin{array}{l}\text { Azithromycin } \\
\text { Duration of therapy (days) }\end{array}$ & $\begin{array}{l}2(1.5 \%) \\
3\end{array}$ & $\begin{array}{l}0 \\
-\end{array}$ & $\begin{array}{l}2(2.5 \%) \\
3\end{array}$ & $\begin{array}{l}\text { Leukocyte count } 2.6(1.4-3.7) \mathrm{G} / \mathrm{L} \\
\text { CRP } 2.9(1.2-4.5) \mathrm{mg} / \mathrm{dL} \\
\text { PCT } 0.1(0.1-0.1) \mathrm{ng} / \mathrm{mL}\end{array}$ \\
\hline $\begin{array}{l}\text { Cephalosporin (cefuroxime, } \\
\text { ceftazidime, ceftriaxone) } \\
\text { Duration of therapy (days) }\end{array}$ & $3(2.2 \%)$ & $\begin{array}{l}2(3.6 \%) \\
13.5(7-20)\end{array}$ & $1(1.3 \%)$ & $\begin{array}{l}\text { Leukocyte count } 7.9(7.5-8.8 .) \mathrm{G} / \mathrm{L} \\
\text { CRP } 8.2(5.2-35) \mathrm{mg} / \mathrm{dL} \\
\text { PCT } 0.2(0.2-0.3 \mathrm{ng} / \mathrm{mL}\end{array}$ \\
\hline $\begin{array}{l}\text { Initial combination therapy of } \\
\text { beta-lactam antibiotic } \\
\text { (+/- azithromycin) with } \\
\text { vancomycin or linezolid }\end{array}$ & $7(5.2 \%)$ & $6(10.7 \%)$ & $1(1.3 \%)$ & $\begin{array}{l}\text { Leukocyte count } 8.8(6.8-14.9) \mathrm{G} / \mathrm{L} \\
\text { CRP } 18.2(0.8-35.0) \mathrm{mg} / \mathrm{dL} \\
\text { PCT } 0.3(0.1-4.9) \mathrm{ng} / \mathrm{mL}\end{array}$ \\
\hline Duration of therapy (days) & $14(4-25)]$ & $10.5(4-25)]$ & 18 & \\
\hline
\end{tabular}

Initial antibiotic therapy was defined as antibiotic therapy within $24 \mathrm{~h}$ of admission. Information on initial empirical antibiotic therapy was not available for 5 patients. Data is presented as absolute numbers and relative frequencies $(n(\%))$. Median duration (days) of every antibiotic regimen is stated as median (range)

Laboratory findings on admission (defined as laboratory results obtained in the ED-encounter which lead to admission of the patient) are presented for different antibiotic regimens

* Median duration of azithromycin-combination-regimens was calculated for beta-lactam antibiotic only; azithromycin was always administered for 3 days. COVID-19, coronavirus disease-2019; ICU, intensive care unit; $C R P$, C-reactive protein; $P C T$, procalcitonin; ED, emergency department

detected in the cohort. Interestingly, two blood infections with vancomycin-resistant $E$. faecium were detected, with molecular confirmation of VanB in both cases. Table 3 summarises the results of the microbiological tests conducted in the present study.

To further investigate the predominance of Enterobacterales and Aspergillus fumigatus in respiratory samples of ICU patients receiving broad-spectrum antimicrobial therapy, the patients were divided into two groups: patients receiving carbapenem therapy and those not receiving carbapenem therapy. Primary or escalation therapy was considered, because retrospective time correlation between the onset of therapy and the microbiologic findings was not possible for all cases. The association between superinfection with Enterobacterales or Aspergillus fumigatus and carbapenem therapy was evaluated. Among the patients without microbiologically detectable co-infection $(n=28,56.0 \%), 14$ patients $(50.0 \%)$ did not undergo carbapenem therapy. Among 
Table 3 Results of microbiologic diagnostics on admission and further relevant microbiological findings during hospitalisation

Full COVID-19 cohort $(n=140) \quad$ Severe COVID-19 patients $(n=56)$

Moderate COVID-19

patients $(n=84)$

\begin{tabular}{|c|c|c|c|}
\hline $\mathrm{BC}$ collected & $118(84.3 \%)$ & $52(92.9 \%)$ & $66(78.6 \%)$ \\
\hline $\mathrm{BC}$ positive & $10(7.1)$ & $5(8.9 \%)$ & $5(6.0 \%)$ \\
\hline Contamination only & $5(3.6 \%)$ & $1(1.8 \%)$ & $4(4.8 \%)$ \\
\hline $\begin{array}{l}\text { BC pathogen in confirmed, } \\
\text { true bacteraemia }\end{array}$ & & $\begin{array}{l}\text { E. coli }(n=1), S \text {. aureus }(n=1) \text {, } \\
\text { S. epidermidis }(n=2)\end{array}$ & E. $\operatorname{coli}(n=1)$ \\
\hline PCT on admission in true bacteraemia & $5.3(0.8-18.7)$ & $5.55(0.8-18.5)$ & 5.9 \\
\hline $\begin{array}{l}\text { PCT on admission in sterile } \\
\text { BC or contamination only }\end{array}$ & $0.1(0.1-15.1)$ & $0.2(0.1-15.1)$ & $0.1(0.1-4.5)$ \\
\hline Follow-up BC diagnostic & $57(40.7 \%)$ & $45(80.4 \%)$ & $12(14.3 \%)$ \\
\hline Cases with positive follow-up $\mathrm{BC}$ & $11(7.9 \%)$ & $10(17.9 \%)$ & $1(1.2 \%)$ \\
\hline Pathogens in positive follow-up BC & & $\begin{array}{l}\text { K. oxytoca }(n=1), K . \text { pneumoniae }(n=1), \\
P . \text { aeruginosa }(n=1), \text { S. epidermidis } \\
(n=2), \text { C. albicans }(n=1), \mathrm{VRE} \\
(n=1), \mathrm{VRE}+C . \text { albicans }(n=1), \\
\text { S. epidermidis }+C \text {. albicans }(n=1), \\
\text { S. epidermidis }+ \text { E. faecium }+ \\
\text { K. varicola }(n=1)\end{array}$ & S. aureus $(n=1)$ \\
\hline $\begin{array}{l}\text { L. pneumophila antigen test } \\
\text { performed; positive rates }\end{array}$ & $111(79.3 \%) ; 0$ & $47(83.9 \%) ; 0$ & $64(76.2 \%) ; 0$ \\
\hline $\begin{array}{l}\text { S. pneumoniae urinary test } \\
\text { performed; positive rates }\end{array}$ & $107(76.4 \%) ; 0$ & $43(76.8 \%) ; 0$ & $64(76.2 \%) ; 0$ \\
\hline $\begin{array}{l}\text { Respiratory samples collected at } \\
\text { admission }\end{array}$ & $25(17.9 \%)$ & $25(44.6 \%)$ & 0 \\
\hline $\begin{array}{l}\text { Clinically relevant pathogens in } \\
\text { respiratory samples at admission* }\end{array}$ & $3(2.1 \%)$ & $\begin{array}{l}3(5.4 \%) \\
\text { E. coli }(n=1), S . \text { aureus }(n=1), K . \text { oxytoca }(n=1)\end{array}$ & 0 \\
\hline $\begin{array}{l}\text { Follow-up microbiological workup of } \\
\text { respiratory samples in ICU } \\
\text { patients }(n=50)^{+}\end{array}$ & & $\begin{array}{l}\text { Follow-up samples collected: } 38(76.0 \%) \\
\text { Detection of relevant pathogens: } 23(46.0 \%) \\
\text { Polymicrobial infection: } 13(26.0 \%) \\
\text { Findings per patient } \\
\text { Enterobacterales: } 17(34.0 \%) \\
\text { A. fumigatus: } 9(18.0 \%) \\
\text { S. aureus: } 3(6.0 \%) \\
\text { P. aeruginosa: } 2(4.0 \%)\end{array}$ & \\
\hline
\end{tabular}

Data is presented as absolute numbers and relative frequencies $(n(\%))$

*Respiratory samples at admission were mainly sputum cultures. Sterile cultures and detection of normal oral flora were regarded as negative in contrast to the detection of relevant pathogens

${ }^{+}$Relevant number of follow-up microbiological tests of respiratory samples was only available for ICU patients

COVID-19, coronavirus disease-2019; ICU, intensive care unit; S. pneumoniae, Streptococcus pneumoniae; L. pneumophila, Legionella pneumophila; E. coli, Escherichia coli; S. aureus, Staphylococcus aureus; K. pneumoniae, Klebsiella pneumoniae; C. albicans, Candida albicans; P. aeruginosa, Pseudomonas aeruginosa; E. faecium, Enterococcus faecium; A. fumigatus, Aspergillus fumigatus; VRE, vancomycin-resistant enterococci; MRSA, methicillin-resistant $S$. aureus; $B C$, blood culture, $P C T$, procalcitonin

the patients with superinfection with Enterobacterales, 6 patients $(46.2 \%)$ did not undergo carbapenem-based therapy. However, Aspergillus fumigatus was detected in the respiratory samples of only 2 patients $(22.2 \%)$ who had not received carbapenem therapy, possibly indicating the adverse antibiotic effect of a broad-spectrum antimicrobial in terms of increased susceptibility to fungal colonisation (Supplementary Fig. 2). The association of the use of carbapenems with the detection of Aspergillus fumigatus was not statistically significant ( $p=$ 0.427 ) and has limited validity due to low patient numbers. Also, this finding must be interpreted with caution as use of carbapenems may just represent more severe cases with
Aspergillus fumigatus as a bystander. Nevertheless, fungal coinfections are an interesting finding in COVID-19 patients [14] and our observation that mainly patients with broadspectrum-antibiotic therapy are affected is still noteworthy and needs to be addressed in further studies.

\section{Discussion}

This descriptive study on the microbiological testing results of COVID-19 patients showed that, at the time of admission, bacteraemia and L. pneumophila or S. pneumoniae infection 
were rarely present, but $46.0 \%$ of severely ill patients admitted to the ICU developed bacterial and fungal co-infections, especially due to Enterobacterales and A. fumigatus.

In patients with clinically suspected bacterial infection or pneumonia, empirical antimicrobial therapy is recommended to be timely initiated even if a causative microorganism cannot be unequivocally identified and often before the results of microbiological diagnostics are available. Antimicrobial treatment might prevent secondary infections and reduce complication rates. However, only pathogen identification and susceptibility testing allows the de-escalation of empirical antimicrobial therapy [29] and increases our knowledge of the bacterial spectrum and antimicrobial resistance, which represents a major pillar of ABS [30]. Diagnostic stewardship is an integral part and the basis for ABS intervention as the appropriate use of microbial diagnostics results in a more sophisticated diagnosis, and can therefore optimise patient management [31, 32]. Multidisciplinary approaches to diagnostic stewardship, as part of an ABS programme, include the development of local guidelines for sample collection. Diagnostic bundles, especially in the ED setting, have been shown to increase the detection of sepsis [33], which is vital for optimal patient care because mortality is reduced when the correct antimicrobial therapy based on the knowledge of local resistance is initiated promptly [34, 35].

Of note, some COVID-19 patients presenting to the ED parallely suffer from additional infectious diseases such as urinary tract infections or skin and soft tissue infections. This must be considered for initiation of adequate diagnostics and empirical therapy. Therefore, requirement of antimicrobial therapy cannot only be only attributed to COVID-19 in our cohort which and must be taken into account when evaluating antibiotic use.

It is of paramount importance for physicians to be aware of the expected spectrum of pathogens of bacterial co-infections in COVID-19 and the corresponding antimicrobial susceptibilities.

Data on bacterial and/or fungal co-infections is sparse, and studies are not consistent regarding the sampling strategies. A $6 \%$ rate of bacteraemia, without further specification, at hospital admission has been reported for 393 COVID-19 patients [36]. These results must be interpreted with caution since there might be a high rate of contamination like in our study, perhaps due to bulky personal protective equipment. In line with our findings, in a report on the microbiological testing of respiratory samples from 99 COVID-19 patients, culture (gram-negative and fungal) growth was only observed for 2 cases $[9,12]$. Widespread antimicrobial use in COVID-19 patients is common, with quinolones being the most commonly used antimicrobials, followed by carbapenems and cephalosporins $[5,37]$. Some national guidelines even specifically advice on the use of broad-spectrum antimicrobials [38].

During the 2003 SARS-CoV-1 outbreak, an increase in MRSA rates among patients admitted to the ICU was noted, and this observation was attributed to the extensive use of broad-spectrum antimicrobials, especially that of cefepime, carbapenems, and fluoroquinolones [39].

ABS in times of COVID-19 is challenging due to biosafety issues for medical staff and laboratory personnel. Guidelines should focus on adequate sampling strategies prior to antibiotic administration and targeted antimicrobial therapy to restrict the overuse of antibiotics to fight emerging resistance and the side effects of antimicrobials. ABS principles could be highly relevant in the management of COVID-19 patients [40]. We implemented local ABS guidelines for diagnostic and therapeutic strategies for suspected COVID-19 patients. Adherence to the guidelines in terms of diagnostics was $>75 \%$, but the detected widespread use of macrolide antibiotics was not favoured by the local ABS guideline. This observation might be due to the overlap of the incidence of COVID-19 with seasonal influenza in spring 2020. Macrolide antibiotics are often initiated to treat atypical pathogens such as Legionella pneumophila. These substances show severe side effects [41] which has to be weighed against the apparently low prevalence of atypical organisms in COVID-19 patients [42].

$\mathrm{BCs}$ are the gold standard and the most important first-line tool for diagnosing severe bacterial infections [43, 44]; however, the diagnostic value of obtaining BCs in the ED setting has been questioned due to frequent false-positive results from contamination and low positivity rates [45]. In our cohort, the diagnostic yield of BCs seems to be remarkably low, but PCT values were higher in patients with true bacteraemia than in those with sterile BC or contaminated BC. Using PCT as a surrogate marker might help to perform more specific $\mathrm{BC}$ diagnostics. Also, PCT was higher in the more severe cases on admission. PCT as a marker for bacterial infections can help to reduce empirical antibiotic use $[9,46]$. In our cohort, elevated PCT levels were associated with the use of broadspectrum antimicrobials, suggesting PCT was used to identify more severe bacterial infections. According to national and international sepsis guidelines, administration of broadspectrum antimicrobial therapy is recommended in severe infections, as indicated by increased inflammatory markers.

Microbiological test results were available mainly for intubated ICU patients, and co-infections with Enterobacterales and A. fumigatus were predominantly observed for these patients. Neither multidrug-resistant gramnegative pathogens nor MRSA were detected in the cohort, but two ICU patients presented with VRE bloodstream infection, highlighting the significance of repetitive microbiological testing in COVID-19 patients admitted in the ICU. Nevertheless, (empirical) carbapenem use was high in ICU patients potentially reflecting severity of disease but still rational revaluation of antibiotic therapy is warranted. The exact incidence of bacterial co-infections in COVID-19 is still unknown [40]. Expansion of microbiological testing of respiratory samples for non-ICU patients should be perused, with 
adequate laboratory staff safety measures, to further increase our knowledge on bacterial co-infections in COVID-19.

The results of the present study should be interpreted with caution due to the limited cohort size. However, considering the number of patients included in the study, we believe that this is a representative COVID-19 cohort for Germany. Larger clinical studies are needed to elucidate the epidemiology, clinical course, and prognostic factors of bacterial co-infections in COVID-19. Due to the nature of the study, only the in-hospital patient course was analysed, no further follow-up data were available, and at the time of analysis, some patients were still hospitalised and undergoing antibiotic treatment, meaning that the final clinical outcome cannot be stated. Due to the retrospective design of this study, respiratory samples were not collected from all patients due to safety concerns. Additional studies on the microbiological findings for COVID-19 patients are needed.

In conclusion, there is a paucity of data on bacterial coinfections in COVID-19 patients. In this study, we found that antimicrobials were being administered at a high rate, but the number of confirmed bacterial infections was low. Severe cases of COVID-19 admitted to the ICU tended to suffer from higher rates of pulmonary enterobacterial and Aspergillus infections than patients with less severe forms of the disease. In future studies, the implication of ABS measures and use of antibiotics in COVID-19 should be carefully assessed, considering the low confirmed rates of bacterial infection.

Authors' contribution KR, CDS, and SF conceived the study. KR, SF, JS, FW, MW, ML, MT, TL, MH, MD, MT, CQ, and AZ contributed to acquisition of the data. KR and CDS analysed the data and interpreted the results. BW performed statistical calculations. KR wrote the manuscript. SF, JS, FW, MW, ML, MT, TL, MH, MD, AZ, BW, CQ, CDS, RMS, GS, and DB revised it critically for important intellectual content. All authors agree with the article submission. All authors read and approved the final manuscript.

Funding Open Access funding enabled and organized by Projekt DEAL.

Data availability All relevant data are made available in the manuscript and supplementary files.

\section{Compliance with ethical standards}

Ethics approval The Ethics Committee of the Technical University of Munich approved the protocol of this retrospective study and waived the need to obtain consent for the collection, analysis, and publication of the retrospectively obtained and anonymised data (approval no. 260/20S).

Conflict of interest The authors declare that they have no conflict of interest.

Open Access This article is licensed under a Creative Commons Attribution 4.0 International License, which permits use, sharing, adaptation, distribution and reproduction in any medium or format, as long as you give appropriate credit to the original author(s) and the source, provide a link to the Creative Commons licence, and indicate if changes were made. The images or other third party material in this article are included in the article's Creative Commons licence, unless indicated otherwise in a credit line to the material. If material is not included in the article's Creative Commons licence and your intended use is not permitted by statutory regulation or exceeds the permitted use, you will need to obtain permission directly from the copyright holder. To view a copy of this licence, visit http://creativecommons.org/licenses/by/4.0/.

\section{References}

1. Lu R, Zhao X, Li J, Niu P, Yang B, Wu H, Wang W, Song H, Huang B, Zhu N, Bi Y, Ma X, Zhan F, Wang L, Hu T, Zhou H, Hu Z, Zhou W, Zhao L, Chen J, Meng Y, Wang J, Lin Y, Yuan J, Xie Z, Ma J, Liu WJ, Wang D, Xu W, Holmes EC, Gao GF, Wu G, Chen W, Shi W, Tan W (2020) Genomic characterisation and epidemiology of 2019 novel coronavirus: implications for virus origins and receptor binding. Lancet (London, England) 395(10224): 565-574. https://doi.org/10.1016/s0140-6736(20)30251-8

2. Wang Z, Yang B, Li Q, Wen L, Zhang R (2020) Clinical features of 69 cases with coronavirus disease 2019 in Wuhan, China. Clin Infect Dis. https://doi.org/10.1093/cid/ciaa272

3. Cevik M, Bamford C, Ho A (2020) COVID-19 pandemic - a focused review for clinicians. Clin Microbiol Infect. https://doi.org/ 10.1016/j.cmi.2020.04.023

4. WHO (2020) Clinical management of severe acute respiratory infection (SARI) when COVID-19 disease is suspected. Interim guidance 13 March 2020

5. Guan WJ, Ni ZY, Hu Y, Liang WH, Ou CQ, He JX, Liu L, Shan H, Lei CL, Hui DSC, Du B, Li LJ, Zeng G, Yuen KY, Chen RC, Tang CL, Wang T, Chen PY, Xiang J, Li SY, Wang JL, Liang ZJ, Peng YX, Wei L, Liu Y, Hu YH, Peng P, Wang JM, Liu JY, Chen Z, Li G, Zheng ZJ, Qiu SQ, Luo J, Ye CJ, Zhu SY, Zhong NS (2020) Clinical characteristics of coronavirus disease 2019 in China. N Eng1 J Med 382(18):1708-1720. https://doi.org/10.1056/ NEJMoa2002032

6. Zhang J, Wang X, Jia X, Li J, Hu K, Chen G, Wei J, Gong Z, Zhou C, Yu H, Yu M, Lei H, Cheng F, Zhang B, Xu Y, Wang G, Dong W (2020) Risk factors for disease severity, unimprovement, and mortality in COVID-19 patients in Wuhan, China. Clin Microbiol Infect. https://doi.org/10.1016/j.cmi.2020.04.012

7. Zhou F, Yu T, Du R, Fan G, Liu Y, Liu Z, Xiang J, Wang Y, Song B, Gu X, Guan L, Wei Y, Li H, Wu X, Xu J, Tu S, Zhang Y, Chen H, Cao B (2020) Clinical course and risk factors for mortality of adult inpatients with COVID-19 in Wuhan, China: a retrospective cohort study. Lancet (London, England) 395(10229):1054-1062. https://doi.org/10.1016/s0140-6736(20)30566-3

8. Lansbury L, Lim B, Baskaran V, Lim WS (2020) Co-infections in people with COVID-19: a systematic review and meta-analysis. J Inf Secur 81(2):266-275. https://doi.org/10.1016/j.jinf.2020.05. 046

9. Rawson TM, Moore LSP, Zhu N, Ranganathan N, Skolimowska K, Gilchrist M, Satta G, Cooke G, Holmes A (2020) Bacterial and fungal co-infection in individuals with coronavirus: a rapid review to support COVID-19 antimicrobial prescribing. Clin Infect Dis. https://doi.org/10.1093/cid/ciaa530

10. Vaughn VM, Gandhi T, Petty LA, Patel PK, Prescott HC, Malani AN, Ratz D, McLaughlin E, Chopra V, Flanders SA (2020) Empiric antibacterial therapy and community-onset bacterial coinfection in patients hospitalized with COVID-19: a multi-hospital cohort study. Clin Infect Dis. https://doi.org/10.1093/cid/ciaa1239

11. Michael J, Cox NL, Bogaert D, O'Grady J (2020) Co-infections: potentially lethal and unexplored in COVID-19. Lancet Microbe. https://doi.org/10.1016/s2666-5247(20)30009-4 
12. Chen N, Zhou M, Dong X, Qu J, Gong F, Han Y, Qiu Y, Wang J, Liu Y, Wei Y, Xia J, Yu T, Zhang X, Zhang L (2020) Epidemiological and clinical characteristics of 99 cases of 2019 novel coronavirus pneumonia in Wuhan, China: a descriptive study. Lancet (London, England) 395(10223):507-513. https:// doi.org/10.1016/s0140-6736(20)30211-7

13. Lescure FX, Bouadma L, Nguyen D, Parisey M, Wicky PH, Behillil S, Gaymard A, Bouscambert-Duchamp M, Donati F, Le Hingrat Q, Enouf V, Houhou-Fidouh N, Valette M, Mailles A, Lucet JC, Mentre F, Duval X, Descamps D, Malvy D, Timsit JF, Lina B, van-der-Werf S, Yazdanpanah Y (2020) Clinical and virological data of the first cases of COVID-19 in Europe: a case series. Lancet Infect Dis. https://doi.org/10.1016/s1473-3099(20)30200-0

14. Koehler P, Cornely OA, Böttiger BW, Dusse F, Eichenauer DA, Fuchs F, Hallek M, Jung N, Klein F, Persigehl T, Rybniker J, Kochanek M, Böll B, Shimabukuro-Vornhagen A (2020) COVID-19 associated pulmonary aspergillosis. Mycoses 63(6): 528-534. https://doi.org/10.1111/myc.13096

15. Zhou P, Liu Z, Chen Y, Xiao Y, Huang X, Fan XG (2020) Bacterial and fungal infections in COVID-19 patients: a matter of concern. Infect Control Hosp Epidemiol:1-2. https://doi.org/10.1017/ice. 2020.156

16. Du Y, Tu L, Zhu P, Mu M, Wang R, Yang P, Wang X, Hu C, Ping R, Hu P, Li T, Cao F, Chang C, Hu Q, Jin Y, Xu G (2020) Clinical features of 85 fatal cases of COVID-19 from Wuhan: a retrospective observational study. Am J Respir Crit Care Med. https://doi. org/10.1164/rccm.202003-0543OC

17. Sticchi C, Alberti M, Artioli S, Assensi M, Baldelli I, Battistini A, Boni S, Cassola G, Castagnola E, Cattaneo M, Cenderello N, Cristina ML, De Mite AM, Fabbri P, Federa F, Giacobbe DR, La Masa D, Lorusso C, Marioni K, Masi VM, Mentore B, Montoro S, Orsi A, Raiteri D, Riente R, Samengo I, Viscoli C, Carloni R (2018) Regional point prevalence study of healthcare-associated infections and antimicrobial use in acute care hospitals in Liguria, Italy. $\mathrm{J}$ Hosp Infect 99(1):8-16. https://doi.org/10.1016/j.jhin.2017.12.008

18. Dellit TH, Owens RC, McGowan JE Jr, Gerding DN, Weinstein RA, Burke JP, Huskins WC, Paterson DL, Fishman NO, Carpenter CF, Brennan PJ, Billeter M, Hooton TM, Infectious Diseases Society of A, Society for Healthcare Epidemiology of A (2007) Infectious Diseases Society of America and the Society for Healthcare Epidemiology of America guidelines for developing an institutional program to enhance antimicrobial stewardship. Clin Infect Dis 44(2):159-177. https://doi.org/10.1086/510393

19. Ewig SGH, Kern WV, Rohde G, Flick H, Krause R, Ott S, Bauer T, Dalhoff K, Gatermann S, Kolditz M, Krueger S, Lorenz J, Pletz M, de Roux A, Schaaf B, Schaberg T, Schuette H, Welte T (2016) Management of adult community-acquired pneumonia and prevention - update 2016 guideline of the German Respiratory Society, the Paul-Ehrlich-Society for Chemotherapy, the German Society for Infectious Diseases, the Competence Network CAPNETZ, the Austrian Respiratory Society, the Austrian Society for Infectious and Tropical Diseases and the Swiss Respiratory Society

20. Stevens MP, Patel PK, Nori P (2020) Involving antimicrobial stewardship programs in COVID-19 response efforts: all hands on deck. Infect Control Hosp Epidemiol 41(6):744-745. https://doi.org/10. 1017/ice. 2020.69

21. Mazdeyasna H, Nori P, Patel P, Doll M, Godbout E, Lee K, Noda AJ, Bearman G, Stevens MP (2020) Antimicrobial stewardship at the Core of COVID-19 response efforts: implications for sustaining and building programs. Curr Infect Dis Rep 22(9):23. https://doi. org/10.1007/s11908-020-00734-x

22. Youngs J, Wyncoll D, Hopkins P, Arnold A, Ball J, Bicanic T (2020) Improving antibiotic stewardship in COVID-19: bacterial co-infection is less common than with influenza. J Inf Secur 81(3):e55-e57. https://doi.org/10.1016/j.jinf.2020.06.056
23. Zhang J, Zhou L, Yang Y, Peng W, Wang W, Chen X (2020) Therapeutic and triage strategies for 2019 novel coronavirus disease in fever clinics. Lancet Respir Med 8(3):e11-e12. https://doi.org/ 10.1016/s2213-2600(20)30071-0

24. Worster A, Bledsoe RD, Cleve P, Fernandes CM, Upadhye S, Eva K (2005) Reassessing the methods of medical record review studies in emergency medicine research. Ann Emerg Med 45(4):448-451. https://doi.org/10.1016/j.annemergmed.2004.11.021

25. Gilbert EH, Lowenstein SR, Koziol-McLain J, Barta DC, Steiner J (1996) Chart reviews in emergency medicine research: where are the methods? Ann Emerg Med 27(3):305-308. https://doi.org/10. 1016/s0196-0644(96)70264-0

26. Corman VM, Landt O, Kaiser M, Molenkamp R, Meijer A, Chu DK, Bleicker T, Brunink S, Schneider J, Schmidt ML, Mulders DG, Haagmans BL, van der Veer B, van den Brink S, Wijsman L, Goderski G, Romette JL, Ellis J, Zambon M, Peiris M, Goossens H, Reusken C, Koopmans MP, Drosten C (2020) Detection of 2019 novel coronavirus (2019-nCoV) by real-time RT-PCR. Euro surveillance : bulletin Europeen sur les maladies transmissibles $=$. Eur Commun Dis Bull 25(3). https://doi.org/10.2807/1560-7917.ES. 2020.25.3.2000045

27. Ai T, Yang Z, Hou H, Zhan C, Chen C, Lv W, Tao Q, Sun Z, Xia L (2020) Correlation of chest CT and RT-PCR testing in coronavirus disease 2019 (COVID-19) in China: a report of 1014 cases. Radiology 200642. https://doi.org/10.1148/radiol.2020200642

28. Kock R, Siemer P, Esser J, Kampmeier S, Berends MS, Glasner C, Arends JP, Becker K, Friedrich AW (2018) Defining multidrug resistance of gram-negative bacteria in the Dutch-German border region-impact of national guidelines. Microorganisms 6(1). https:// doi.org/10.3390/microorganisms6010011

29. de With K, Allerberger F, Amann S, Apfalter P, Brodt HR, Eckmanns T, Fellhauer M, Geiss HK, Janata O, Krause R, Lemmen S, Meyer E, Mittermayer H, Porsche U, Presterl E, Reuter S, Sinha B, Strauss R, Wechsler-Fordos A, Wenisch C, Kern WV (2016) Strategies to enhance rational use of antibiotics in hospital: a guideline by the German Society for Infectious Diseases. Infection 44(3):395-439. https://doi.org/10.1007/ s15010-016-0885-z

30. Mathieu C, Pastene B, Cassir N, Martin-Loeches I, Leone M (2018) Efficacy and safety of antimicrobial de-escalation as a clinical strategy. Expert Rev Anti-Infect Ther. https://doi.org/10.1080/ 14787210.2019 .1561275

31. WHO (2016) Diagnostic stewardship - a guide to implementation in antimicrobial resistance surveillance sites

32. Patel R, Fang FC (2018) Diagnostic stewardship: opportunity for a laboratory-infectious diseases partnership. Clin Infect Dis 67(5): 799-801. https://doi.org/10.1093/cid/ciy077

33. Whippy A, Skeath M, Crawford B, Adams C, Marelich G, Alamshahi M, Borbon J (2011) Kaiser Permanente's performance improvement system, part 3: multisite improvements in care for patients with sepsis. Jt Comm J Qual Patient Saf 37(11):483-493

34. Singer M, Deutschman CS, Seymour CW, Shankar-Hari M, Annane D, Bauer M, Bellomo R, Bernard GR, Chiche JD, Coopersmith CM, Hotchkiss RS, Levy MM, Marshall JC, Martin GS, Opal SM, Rubenfeld GD, van der Poll T, Vincent JL, Angus DC (2016) The third international consensus definitions for sepsis and septic shock (sepsis-3). Jama 315(8):801-810. https://doi.org/ 10.1001/jama.2016.0287

35. Ferrer R, Martinez ML, Goma G, Suarez D, Alvarez-Rocha L, de la Torre MV, Gonzalez G, Zaragoza R, Borges M, Blanco J, Herrejon EP, Artigas A, Group AB-ES (2018) Improved empirical antibiotic treatment of sepsis after an educational intervention: the ABISSEdusepsis study. Crit Care (Lond, Engl) 22(1):167. https://doi.org/ 10.1186/s13054-018-2091-0

36. Goyal P, Choi JJ, Pinheiro LC, Schenck EJ, Chen R, Jabri A, Satlin MJ, Campion TR Jr, Nahid M, Ringel JB, Hoffman KL, Alshak 
MN, Li HA, Wehmeyer GT, Rajan M, Reshetnyak E, Hupert N, Horn EM, Martinez FJ, Gulick RM, Safford MM (2020) Clinical characteristics of Covid-19 in New York City. N Engl J Med. https://doi.org/10.1056/NEJMc2010419

37. Cao J, Tu WJ, Cheng W, Yu L, Liu YK, Hu X, Liu Q (2020) Clinical features and short-term outcomes of 102 patients with corona virus disease 2019 in Wuhan, China. Clin Infect Dis. https:// doi.org/10.1093/cid/ciaa243

38. Nicastri E, Petrosillo N, Bartoli TA, Lepore L, Mondi A, Palmieri F, D'Offizi G, Marchioni L, Murachelli S, Ippolito G, Antinori A (2020) National Institute for the infectious diseases "L. Spallanzani", IRCCS. Recommendations for COVID-19 clinical management. Infect Dis Rep 12(1):8543. https://doi.org/10.4081/ idr.2020.8543

39. Yap FH, Gomersall CD, Fung KS, Ho PL, Ho OM, Lam PK, Lam DT, Lyon DJ, Joynt GM (2004) Increase in methicillin-resistant Staphylococcus aureus acquisition rate and change in pathogen pattern associated with an outbreak of severe acute respiratory syndrome. Clin Infect Dis 39(4):511-516. https://doi.org/10.1086/ 422641

40. Huttner B, Catho G, Pano-Pardo JR, Pulcini C, Schouten J (2020) COVID-19: don't neglect antimicrobial stewardship principles! Clin Microbiol Infect. https://doi.org/10.1016/j.cmi.2020.04.024

41. Mason JW (2017) Antimicrobials and QT prolongation. J Antimicrob Chemother 72(5):1272-1274. https://doi.org/10.1093/ jac/dkw591
42. Kim D, Quinn J, Pinsky B, Shah NH, Brown I (2020) Rates of coinfection between SARS-CoV-2 and other respiratory pathogens. Jama. https://doi.org/10.1001/jama.2020.6266

43. Dubourg G, Raoult D, Fenollar F (2019) Emerging methodologies for pathogen identification in bloodstream infections: an update. Expert Rev Mol Diagn:1-13. https://doi.org/10.1080/14737159. 2019.1568241

44. Lamy B, Dargere S, Arendrup MC, Parienti JJ, Tattevin P (2016) How to optimize the use of blood cultures for the diagnosis of bloodstream infections? A state-of-the art. Front Microbiol 7:697. https://doi.org/10.3389/fmicb.2016.00697

45. Kelly AM (1998) Clinical impact of blood cultures taken in the emergency department. J Accid Emerg Med 15(4):254-256

46. Schuetz P, Wirz Y, Sager R, Christ-Crain M, Stolz D, Tamm M, Bouadma L, Luyt CE, Wolff M, Chastre J, Tubach F, Kristoffersen KB, Burkhardt O, Welte T, Schroeder S, Nobre V, Wei L, Bucher HC, Bhatnagar N, Annane D, Reinhart K, Branche A, Damas P, Nijsten M, de Lange DW, Deliberato RO, Lima SS, MaravicStojkovic V, Verduri A, Cao B, Shehabi Y, Beishuizen A, Jensen JS, Corti C, Van Oers JA, Falsey AR, de Jong E, Oliveira CF, Beghe B, Briel M, Mueller B (2017) Procalcitonin to initiate or discontinue antibiotics in acute respiratory tract infections. Cochrane Database Syst Rev 10:Cd007498. https://doi.org/10. 1002/14651858.CD007498.pub3

Publisher's note Springer Nature remains neutral with regard to jurisdictional claims in published maps and institutional affiliations. 